\title{
PEMIKIRAN ȘADR AL-DĪN AL-SHĪRĀZĪ TENTANG WUJUD
}

\section{ȘADR AL-DĪN AL-SHĪRĀZĪ'S THOUGHT ON EXISTENCE}

\section{Mohd Syahmir Alias}

Section of Philosophy \& Civilisation. School of Humanities. Universiti Sains Malaysia. 11800. Pulau

Pinang. Malaysia.

Email: syahmir@usm.my

DOI: https://doi.org/10.22452/afkar.vol21 no2.1

\begin{abstract}
Șadr al-Dīn al-Shīrāzī (1572-1640) or Mullā Șadrā was a later development Muslim philosopher from Persia. He was said to be the pioneer of a new thought in Islamic philosophy which followed the former Muslim philosophers such as Ibn Sīnā and Ibn Rushd. His thoughts are increasingly being studied by scholars of Islamic philosophy over the past few decades. This article aims to identify Șadr al-Dīn alShīrāzì's thought with regards to his conception on existence. The article collects documents related to Șadr ad-Dīn al-Shīrāzī's thought based on the document study method, then analyses it through textual analysis method. As a result, this article discovers that Șadr ad-Dīn al-Shīrāzī introduced the principle of primacy of existence or așālah al-wujūd in his philosophical system, which differs from his predecessor, Suhrawardī, that emphasizes on the primacy of quiddity or așālath al-māhiyyah. Șadr adDīn al-Shīrāzī's thought also has some effect to human substance -the soul, through his principle of substantial movement or al-harakāt al-jawhariyyah. These principles initiate a new interpretation in Islamic philosophy especially with regards to the dynamicity of creation of everything that exists.
\end{abstract}

Keywords: Șadr ad-Dīn al-Shīrāzī; Mullā Șadrā; primacy of existence; primacy of essence; soul. 
Mohd Syahmir, "Pemikiran Sadr al-Din al-Shirazi tentang Wujud," Afkār Vol.

21 Issue 2 (2019): 1-32

\section{Khulasah}

Șadr al-Dīn al-Shīrāzī (1572-1640) atau Mullā Șadrā, seorang ahli falsafah Muslim terkemudian yang berasal dari Parsi. Beliau dikatakan sebagai perintis kepada suatu pemikiran baharu dalam falsafah Islam selepas berlalunya pemikiran ahli-ahli falsafah Muslim terdahulu seperti Ibn Sīnā dan Ibn Rushd. Pemikiran beliau semakin banyak dikaji oleh pengkaji falsafah Islam sejak beberapa dekad yang lalu. Makalah ini bertujuan untuk mengenal pasti pemikiran Șadr al-Dīn al-Shīrāzī, khususnya berkenaan konsepsi beliau mengenai wujud. Makalah ini mengumpul dokumen berkaitan pemikiran Șadr al-Dīn al-Shīrāzī berasaskan kaedah kajian dokumen, seterusnya menganalisisnya berasaskan kaedah analisis teks. Hasilnya, makalah ini mendapati bahawa Șadr al-Dīn al-Shīrāzī memperkenalkan prinsip keasalan wujud atau aṣālath al-wujūd dalam sistem falsafahnya. Prinsip ini berbeza daripada pemikiran ahli falsafah sebelumnya iaitu Suhrawardī yang menekankan prinsip keasalan zat atau așālah al-māhiyyah. Pemikiran Șadr al-Dīn al-Shīrāzī tentang wujud memberi kesan kepada jauhar manusia iaitu jiwa melalui prinsip pergerakan jauhar atau al-harakat aljawhariyyah. Prinsip-prinsip ini membuka tafsiran baharu dalam falsafah Islam khususnya mengenai kedinamikan penciptaan setiap yang wujud.

Kata kunci: Șadr al-Dīn al-Shīrāzī; Mullā Șadrā; keasalan wujud; keasalan zat; jiwa.

\section{Pengenalan}

Șadr al-Dīn Muḥammad ibn Ibrāhīm ibn Yahyā Qawāmi alShīrāzì atau juga dikenali sebagai Mullā Șadrā merupakan seorang ahli falsafah Muslim yang semakin mendapat tempat dalam penyelidikan falsafah Islam sejak beberapa dekad yang lalu. ${ }^{1}$ Hal ini terbukti dengan wujudnya

1 Seyyed Hossein Nasr, Sadr ad-Dīn Shīrāzī and His Transcendent Theosophy: Background, Life and Works (Tehran: Imperial Iranian Academy of Philosophy, 1978), 19. 
beberapa interpretasi yang berbeza oleh ahli falsafah kontemporari yang melakukan kajian terhadap pemikiran falsafah beliau.

Menurut Ernst, sekurang-kurangnya terdapat dua kumpulan pemikir kontemporari yang berbeza pandangan mengenai pemikirannya. Pertama ialah kumpulan Seyyed Hossein Nasr, Henry Corbin dan James Winston Morris yang berhujah bahawa Șadr al-Dīn al-Shīrāzī merupakan pemikir yang cenderung ke arah kebatinan dan mistik (esoteric and mystical). Kedua pula ialah kumpulan Fazlur Rahman, Hossein Ziai dan John Wallbridge yang mempertahankan bahawa Sadr al-Dīn al-Shīrāzī merupakan pemikir yang wajar didekati dengan falsafah analitis moden (analytical philosophy). ${ }^{2}$

Sungguhpun terdapat perbezaan pendapat mengenai posisi pemikiran falsafahnya, Șadr al-Dīn al-Shīrāzī dikatakan telah membawa suatu pemikiran baharu dalam penyelidikan falsafah Islam selepas berlalunya pemikiran ahli-ahli falsafah tamadun Islam sebelah barat seperti Ibn Rushd. ${ }^{3}$ Beliau dianggap berjaya menyatukan tiga keperluan asas seorang ahli falsafah Muslim iaitu pertama, beriman kepada wahyu; kedua, menaakul secara logik menggunakan akal; dan ketiga, keperluan menjalani kehidupan rohani yang kudus untuk mencapai pencerahan (illumination) daripada Allah SWT. ${ }^{4}$

Menyedari penyatuan keperluan-keperluan tersebut sebagai seorang ahli falsafah Muslim, beliau membincangkan konsepsi berkenaan wujud (wujūdlexistence) sehingga melahirkan suatu sistem metafizik atau sistem ontologi yang unik dikenali sebagai

2 Carl W. Ernst, "Sufism and Philosophy in Mulla Sadra" (kertas kerja, World Congress on Philosophy of Mulla Sadra, Tehran, Mei 1999), 2.

3 Toshihiko Izutsu, The Concept and Reality of Existence (Kuala Lumpur: Islamic Book Trust, 2007), 92-94.

${ }^{4}$ Zailan Moris, Revelation, Intellectual Intuition and Reason in the Philosophy of Mulla Sadra: An Analysis of the al-Hikmah al'Arshiyyah (New York: RoutledgeCurzon, 2003), 1-2. 
Mohd Syahmir, "Pemikiran Sadr al-Din al-Shirazi tentang Wujud," Afkār Vol.

21 Issue 2 (2019): 1-32

'hikmah tertinggi' atau 'al-hikmah al-muta 'āliyyah'.5 Menurut Cooper, sistem ontologi yang berubah secara akar umbi dan berbeza daripada ahli falsafah Muslim sebelumnya menjadikan Șadr al-Dīn al-Shīrāzī sebagai seorang penyumbang yang asli terhadap sistem epistemologi. ${ }^{6}$ Hal ini kerana, beliau telah menggabungkan antara aspek teori Ibn Sīnā mengenai aktualisasi akal manusia oleh akal aktif dengan teori Suhrawardī berkenaan ilmu hudūūī (ilmu yang hadir). ${ }^{7}$

Oleh yang demikian, makalah ini bertujuan mengenal pasti pemikiran Șadr al-Dīn al-Shīrāzī dalam falsafah Islam, khususnya mengenai konsepsi beliau berkaitan wujud. Tujuan makalah ini meneliti subjek tersebut adalah kerana, menurut Seyyed Hossein Nasr, wujud merupakan perbincangan yang sangat penting dalam falsafah Islam

${ }^{5}$ Megawati Moris, Mullā Sadrā's Doctrine of the Primacy of Existence (Așālat al-Wujūd) (Kuala Lumpur: International Institute of Islamic Thought and Civilization, International Islamic University Malaysia, 2003), 9 .

${ }^{6}$ Muhammad Nur, Wahdah al-Wujud Ibn 'Arabi dan Filsafat Wujud Mulla Shadra (Makassar: Chamran Press, 2012): 64.

7 John Cooper, "Mulla Sadra (Sadr al-Din Muhammad al-Shirazi) (15711640)", dicapai 19 Januari http://www.muslimphilosophy.com/ip/rep/H027.htm. Untuk mengenali teori aktualisasi akal oleh Ibn Sīnā, rujuk Mohamed Safiullah Munsoor \& Che Zarrina Saari, "Knowledge and Islam on the Non-Rational and Rational-Heart-Brain Inter-Connection: A Classical Islamic Scholarly Perspective”, Afkar 19, issue 1, (2017): 145. Suhrawardī atau nama penuhnya, Shihāb ad-Dīn Yahyā ibn Habash ibn Amīrak Abū'l-Futūh Suhrawardī ialah pengasas aliran falsafah hikmah al-ishraqiyyah. Beliau hidup sezaman dengan Fakhr al-Dīn al-Rāzī dan sama-sama berguru dengan Majd ad-Dīn al-Jīlī. Untuk mengetahui lebih lanjut mengenai aliran Suhrawardī, rujuk Amroeni Drajat, Suhrawardi: Kritik Falsafah Peripatetik (Yogyakarta: LKiS, 2005), 29-31. Untuk mengenali salah satu aspek pemikiran Fakhr ad-Dīn ar-Rāzī, rujuk Che Zarrina Saari \& Mohd Manawi Mohd Akib, "Beberapa Persoalan Berkaitan Konsep Insan Menurut Fakhr al-Dīn al-Rāzī”, Afkar 19, Special Issue, (2017): 93. 
khususnya metafizik Islam ${ }^{8}$. Justeru, makalah ini dibentuk melalui kajian dokumen menggunakan data sekunder iaitu karya-karya Șadr ad-Dīn ash-Shīrāzī dan penulisan berkenaan pemikirannya. Seterusnya, analisis kandungan dijalankan memandangkan kaedah-kaedah tersebut bersesuaian dengan kajian terhadap data sekunder yang digunakan.

Dari sudut perbincangan pula, makalah ini terbahagi kepada empat bahagian khusus. Pertama, menyoroti kehidupan dan karya Șadr al-Dīn al-Shīrāzī. Kedua, membincangkan pembahagian wujud dalam falsafah Islam. Ketiga, meneliti pemikiran Șadr al-Dīn al-Shīrāzī tentang wujud. Keempat, impak pemikiran wujud Șadr al-Dīn alShīrāzī terhadap huraian mengenai jiwa manusia. Pada bahagian yang terakhir, makalah ini melakarkan rajah untuk meringkaskan konsepsi wujud menurut pemikiran Șadr al-Dīn al-Shīrāzī.

\section{Latar Belakang Șadr al-Dīn al-Shīrāzī}

Șadr al-Dīn al-Shīrāzì digelar sebagai "al-Hakīm al-Ilāhī wa al-Faylasūf al-Rabbān $\vec{\imath} .{ }^{9}$ Beliau merupakan seorang anak tunggal yang dilahirkan pada tahun 1571M di Shiraz, sebuah kota yang kini terletak di Safawi, Iran. ${ }^{10}$ Empayar Safawi ketika itu berada di bawah pemerintahan Shāh 'Abbās I (m. 1629M) yang merupakan sebuah negeri berlandaskan ajaran Shī'ah Ithnā 'Asharīyyah atau Syiah

\footnotetext{
${ }^{8}$ Seyyed Hossein Nasr, "Existence (Wujūd) and Quiddity (Māhiyyah) in Islamic Philosophy", International Philosophical Quarterly vol. 24, no. 4, issue 116, (December 1989), 409.

${ }^{9} \mathrm{Hal}$ ini sebagaimana yang tercatat pada adikaryanya al-Hikmah alMuta 'āliyyah. Rujuk Sadr al-Dīn Muhammad al-Shīrāzì, al-Hikmah al-Muta 'āliyyah fì al-Asfār al- 'Aqliyyah al-Arba 'ah, I-IX (Beirut: Dār Ihyā' at-Turath al-'Arabī, 1990).

10 Sajjad H. Rizvi, Mulla Sadra Shirazi: His Life and Works and the Sources for Safavid Philosophy (New York: Oxford University Press, 2007), 5.
} 
Imam Dua Belas. ${ }^{11}$ Beliau meninggal dunia sekitar tahun 1641M ketika dalam perjalanan menunaikan haji ketujuhnya di Mekah dan disemadikan di Najaf, bersebelahan makam Saidina 'Alī bin Abī Țālib. ${ }^{12}$

Keseluruhan hidup Șadr al-Dīn al-Shīrāzī merupakan suatu terapan daripada doktrin metafiziknya yang diperoleh daripada visi metafiziknya (wijdān atau ecstasis). Secara terperinci, sejarah hidup beliau dapat dibahagikan kepada tiga jangka masa berasaskan tempat tertentu. Pertama, ketika di Shiraz dan Isfahan iaitu jangka masa beliau mendapat pendidikan formal berkenaan ilmu-ilmu tradisi Islam. Kedua, ketika di Kahak iaitu jangka masa beliau melakukan pembersihan jiwa dan hidup dalam keadaan yang penuh zuhud. Ketiga, ketika beliau kembali semula ke Shiraz untuk melaksanakan tugas mengajar kepada masyarakat dan menulis kitab-kitab sebagai bimbingan kepada para muridnya. ${ }^{13}$

Șadr al-Dīn al-Shīrāzī menerima pendidikan formal daripada sejumlah guru-guru yang berwibawa. Antara guru beliau ialah Mīr Muhammad Bāqir Dāmād Astarabadi, Bahā'u'd-Dīn 'Āmili dan Mīr Abū al-Qāsim Fendereskī. ${ }^{14}$ Hasil daripada pembelajaran dalam bidang kalam, falsafah dan tasawuf khususnya, Șadr al-Dīn al-Shīrāzì menulis beberapa karya penting yang menggambarkan perjalanan spiritual dan ketinggian intelektualnya. Antara tulisan tersebut ialah pertama, al-Hikmah al-Muta'äliyyah fì al-

${ }^{11}$ Mashhad al-Allaf, The Essential Ideas of Islamic Philosophy: A Brief Survey (New York: The Edwin Mellen Press, 2006), 315.

${ }^{12}$ Seyyed G. Safavi, "Mulla Sadra's Life and Philosophy", Trancendent Philosophy 13, (December 2012), 22.

${ }^{13}$ Nasr, Sadr ad-Dīn Shīrāzi and His Transcendent Theosophy, 38.

${ }^{14}$ Alparslan Açıkgenç, Being and Existence in Șadrā and Heidegger: A Comparative Ontology (Kuala Lumpur: International Institute of Islamic Thought and Civilization, International Islamic University Malaysia, 1993), 13; Sajjad Rizvi, "Mulla Sadra", The Stanford Encyclopedia of Philosophy, dicapai 6 Ogos 2017, http://plato.stanford.edu/entries/mulla-sadra/.2009. 
Asfār al-'Aqliyyah al-Arba'ah (Kitab Hikmah Tertinggi Berkaitan Empat Perjalanan Akal); kedua, al-Hikmah al'Arshiyyah (Kitab Hikmah dari Arasy); ketiga, al-Mashā 'ìr (Kitab Penembusan Metafizik); keempat, Iksīr al-'Ärifin fí Ma'rifat Tariq al-Haqq wa al-Yaqin (Kitab Iksir Orang Arif Berkaitan Makrifat Jalan kepada Kebenaran dan Keyakinan); dan kelima, al-Mabda' wa al-Ma 'ād (Kitab Permulaan dan Pengakhiran). ${ }^{15}$

Adikaryanya iaitu al-Hikmah al-Muta'āliyyah dibahagikan kepada empat bahagian musafir. Musafir pertama, 'min al-khalq ilā al-haqq' menjelaskan tentang ontologi khususnya berkaitan zat (māhiyah), wujud (wujūd), pergerakan (harakah), sebab-akibat (sababiyyah) dan teori rupa Plato (al-muthul al-Aflātūniyyah). Musafir kedua 'bi al-haqq fi al-haqq' membincangkan mengenai falsafah tabii seperti jauhar (bahan/jawhar/substance), arad (sifat/'arad/accident) dan sepuluh kategorinya menurut Aristotle. Musafir ketiga ' $m i n$ al-haqq ilā al-khalq bi alhaqq' menangani perbahasan mengenai wujud Tuhan dan sifat-sifat-Nya. Musafir keempat 'bi al-haqq fi al-khalq' pula menjelaskan tabii manusia, kewujudan dan takdirnya. ${ }^{16}$

Selain dikenali sebagai musafir, ia juga disebut sebagai suluk akliah yang memperlihatkan keempat-empat musafir itu merupakan sebuah perjalanan yang melibatkan akal secara perbakatan (bi al-quwwah atau potential), akal secara perbuatan (bi al-fi'l atau actual), akal tabiat (disposition) dan akal perolehan (mustafād atau acquired) yang seterusnya bersatu dengan akal aktif. ${ }^{17}$ Dalam penghasilan adikaryanya ini, beliau banyak dipengaruhi oleh pemikiran ahli sufi falsafi terkenal daripada aliran

\footnotetext{
${ }^{15}$ Al-Allaf, The Essential Ideas of Islamic Philosophy, 316-317.

${ }^{16}$ Al-Shīrāzī, al-Hikmah al-Muta' 'āliyyah, I, 13.

${ }^{17}$ Nur, Wahdah al-Wujud Ibn 'Arabi dan Filsafat Wujud Mulla Shadra, 64.
} 
Akbarī iaitu Ibn 'Arabī dan ahli falsafah beraliran Ishraqī (Iluminasi) iaitu Suhraward̄̄. ${ }^{18}$

Oleh sebab Șadr al-Dīn al-Shīrāzī kurang terkenal di luar daripada lingkungan negara Iran atau umumnya di wilayah Parsi, pengaruh falsafahnya juga dikatakan tidak sebanding falsafah Ibn Sīnā yang berjaya sampai ke Eropah dan dunia Barat umumnya. ${ }^{19}$ Malah, penulisan yang agak awal mengenai pemikiran beliau dalam bahasa Inggeris hanya diterbitkan pada tahun 1975 dan ditulis secara komprehensif oleh Fazlur Rahman. ${ }^{20}$ Di lingkungan Iran, terdapat murid-murid beliau yang meneruskan legasi pemikirannya, antaranya ialah Mullā Muḥsin Fayḍ Kāshān̄̄ dan 'Abd al-Razzāq Lāhījīi. ${ }^{21}$

\section{Pengelasan Wujud dalam Falsafah Islam}

Sebelum dijelaskan pandangan Șadr al-Dīn al-Shīrāzī berkenaan wujud, makalah ini meneliti terlebih dahulu pengelasan atau pengkategorian wujud dalam falsafah Islam. Dari sudut sejarah, pembahagian antara wujud dengan zat (māhiyyah/quiddity/essence) berpunca daripada pembahagian ahli falsafah Muslim beraliran Mashā' (Peripatetik) terdahulu, iaitu secara khususnya Ibn Sīnā. ${ }^{22}$ Beliau menjelaskan bahawa dalam menganalisis sesuatu perkara yang wujud atau mawjüd (existent), minda manusia dapat menerbitkan dua bentuk persoalan iaitu pertama, “apakah ia (itu)?”; dan kedua, "adakah ia (itu ada)?”.

18 Ibid., 316; Nasr, Șadr ad-Dīn Shīrāzì and His Transcendent Theosophy, 41.

${ }^{19}$ Açıkgenç, Being and Existence in Sadrā and Heidegger, 15.

20 Fazlur Rahman, The Philosophy of Mullā Sadrā (Șadr ad-Dīn Muhammad Shīrāzì) (Lahore: Suhail Academy, 2005); Hamid Fahmy Zarkasyi, "The Philosophy of Mulla Sadra: Being a Summary of His Book al-Hikmah al-Muta 'äliyah fi al-Asfār al- 'Aqliyyah al-Arba 'ah', TSAQAFAH 5, no. 2 (2009), 326.

21 Muhammad Kamal, Mulla Sadra's Transcendent Philosophy (Aldershot: Ashgate, 2006), 3; Nasr, Șadr ad-Dīn Shīrāzī and His Transcendent Theosophy, 38.

${ }^{22}$ Rahman, The Philosophy of Mullā Sadrā,, 27. 
Soalan pertama dijawab dengan menyatakan māhiyyahnya, manakala soalan kedua dijawab sama ada wujud atau tidak wujud sesuatu itu. Sungguhpun dapat dipertanyakan dua soalan tersebut, namun kedua-duanya tidak terpisah antara satu sama lain kerana pemisahan itu berlaku hanya di minda manusia. ${ }^{23}$ Walau bagaimanapun, perkara yang menjadi persoalan dalam kalangan ahli falsafah Muslim terkemudian pula adalah, antara jawapan bagi kedua-dua persoalan tersebut, manakah yang merupakan asal kepada sesuatu yang ditanggapi dan manakah pula yang merupakan iktibar atau abstraksi atau yang dipersepsikan dalam minda?

Justeru, Suhrawardī dalam sistem metafiziknya mengangkat māhiyyah sebagai asal segala sesuatu dan doktrinnya disebut sebagai așālah al-māhiyyah. Walaupun pada awal usianya, beliau berpegang kepada doktrin tersebut, Șadr al-Dīn al-Shīrāzì kemudiannya mengkritik doktrin tersebut dan mengangkat wujud sebagai asal segala sesuatu atau așālah al-wujūd. ${ }^{24}$ Menurut Kalin, sistem ontologi essentialism Suhrawardī dan existentialism Șadr al-Dīn al-Shīrāzī berbeza disebabkan oleh demonstrasi rasional (burhān) dan kesimpulan yang mereka lakukan melalui penaakulan kewacanaan (discursive reasoning). Hal ini kerana, kedua-dua ahli falsafah ini mendakwa mereka mengalami sendiri hakikat melalui kaedah dhawq (rasa) dan shuhūd (penyaksian) sebagaimana yang dialami oleh ahli sufi yang sebenar. ${ }^{25}$

Secara umumnya, wujud dibahagikan kepada tiga kategori iaitu wujud yang wajib (wājib al-wujūd), wujud

${ }^{23}$ Hossein Sheykh Rezaee \& Mohammad Mansur Hashemi, "Knowledge as a Mode of Being: Mulla Sadra's Theory of Knowledge", Sophia Perennis 4, (Autumn 2009), 21; Moris, Mullā Sadrā's Doctrine of the Primacy of Existence, 11.

${ }^{24}$ Rahman, The Philosophy of Mullā Sadrā, 31-32.

${ }^{25}$ Ibrahim Kalin, Knowledge in Later Islamic Philosophy: Mullā Șadrā on Existence, Intellect and Intuition (Oxford: Oxford University Press, 2010), 206. 
yang mungkin (mumkin al-wujūd) dan wujud yang mustahil (mumtani" al-wujūd). Menurut Nasr, pembahagian ini terawal sekali telah dilakukan oleh Ibn Sīnā dalam karyakaryanya seperti Kitāb al-Shifā' dan Kitāb al-Najāt. Pembahagian ini mempunyai signifikannya baik kepada ilmu falsafah, mahupun ilmu kalam (teologi) dan ilmu tasawuf. Berkenaan kategori pertama, wäjib al-wujūd akan menjadi bertentangan pada akal sekiranya ia tidak ada, justeru menjadikannya mesti ada. Oleh yang demikian, istilah ini seringkali digunakan sebagai istilah falsafah yang merujuk kepada Tuhan atau Allah SWT. ${ }^{26}$

Berkenaan hujah akliah keesaan Wājib al-Wujūd, menurut Șadr al-Dīn al-Shīrāzī, setiap dua benda mempunyai sifat keduaannya (ithnayniyyah). Ia sama ada zat dan hakikat, atau hakikat di luar (khārijān) dan hakikat dalam minda (dhihnān), atau kesempurnaan (kamāliyyah) dan kekurangan (naqs) pada hakikat yang dikongsi (nafs alhaqīqah al-mushtarikah), atau disebabkan oleh perbuatan ' arad yang ditambahkan kepada satu-satu jauhar (amr za' 'id 'āriḍ). ${ }^{27}$ Walau bagaimanapun, aspek-aspek ini tidak menyebabkan kejamakan pada Wājib al-Wujūd kerana empat sebab seperti yang dikatakan oleh beliau iaitu ${ }^{28}$ :

"... yang pertama oleh sebab kesatuan Hakikat Wujud (ittihâad haqīqah al-wujūd), yang kedua oleh sebab keringkasan-Nya (basātah), yang ketiga oleh sebab keutuhan Zat yang Wajib (tamāmiyyah al-dhāt al-wājibiyyah) kerana setiap kekurangan adalah dihadkan oleh penyebab selainnya, dan yang keempat oleh sebab ketidakmungkinan Wujud yang Wajib

26 Nasr, "Existence $(W u j \bar{u} d)$ and Quiddity (Māhiyyah) in Islamic Philosophy", 418.

${ }^{27}$ Șadr al-Dīn Muhammad al-Shīrāz̄̄, al-Maẓāhir al-Ilāhiyyah fī Asrār al- 'Ulūm al-Kamāilyyah, ed. al-Sayyid Jalāl al-Dīn al-Āshtiyānī (Iran: Mu'assasah Būstān Kitāb, 2008), 77.

${ }^{28}$ Ibid. 
didahului oleh pemberi sifat luaran (mukhașșaṣ khārij̄i)."

Sekiranya wujud pemberi sifat atau agen luaran, maka ia wajib didahului oleh hakikat wujud sebelumnya dan hal ini berulang-ulang sehingga ketidakberhinggaan. Oleh yang demikian, Zat Allah yang wajib diindividukan dengan Zat-Nya (muta'ayyunah bi dhātihā). ${ }^{29}$ Justeru, apa jua selain daripada-Nya ( $m \bar{a}$ siwā Allāh) dikategorikan sebagai mumkin al-wujūd iaitu kategori kedua wujud. Mumkin alwujūd ialah wujud yang boleh jadi ada atau tidak ada, dan ia tidak menimbulkan sebarang kontradiksi pada akal sekiranya ia ada ataupun tidak ada. Kategori ini selalunya dikaitkan dengan alam semesta berserta semua isinya termasuklah manusia yang memerlukan wujud di luar daripada dirinya untuk mewujudkannya. ${ }^{30}$ Perkara ini selaras dengan ayat-ayat al-Quran yang menerangkan apabila Allah SWT, iaitu Wäjib al-Wujūd, berkehendakkan sesuatu, Dia hanya berfirman kepadanya, "jadilah". Hal ini misalnya sebagaimana yang terdapat dalam ayat berikut, maksudnya $^{31}$ :

"Allah jua yang menciptakan langit dan bumi, dan apabila Dia berkehendak (untuk menjadikan) sesuatu, maka Dia berfirman kepadanya 'jadilah', maka menjadilah ia."

Kategori yang ketiga pula ialah mumtani' al-wujūd iaitu sesuatu itu mustahil untuk ia ada kerana ia akan mengakibatkan percanggahan kepada akal yang sihat dan

29 Ibid. .

30 Nasr, "Existence (Wujūd) and Quiddity (Māhiyyah) in Islamic Philosophy", 417.

${ }^{31}$ Al-Quran 2:117, terj. Abdullah Muhammad Basmeih, Tafsir Pimpinan ar-Rahman kepada Pengertian al-Qur'an, ed. Muhammad Noor Ibrahim (Kuala Lumpur: Darul Fikir, 2001). Pernyataan yang serupa juga terdapat dalam ayat-ayat berikut: al-Quran 3:47, al-Quran 3:59, al-Quran 6:73, al-Quran 16:40, al-Quran 19:35, al-Quran 36:82 dan al-Quran 40:68. 
berfikiran logik. Misalnya adalah seperti wujudnya sekutu kepada Maha Pencipta atau suatu kuantiti yang lebih besar daripada penjumlahan bahagian-bahagiannya. Perkaraperkara seperti ini masih boleh difikirkan oleh akal manusia, namun pernyataannya tidak dapat diterima kerana pertentangan yang terdapat padanya. ${ }^{32}$

Selain pengkategorian wujud kepada tiga kategori ini dalam falsafah Islam, Șadr al-Dīn al-Shīrāzī yang meyakini sepenuhnya ontologi sufi Ibn 'Arabī membahagikan wujud kepada tiga peringkat atau martabat (marātib al-wujūd). ${ }^{33}$ Martabat pertama ialah Wujud Murni (al-Wujūd aș-Sarf) iaitu wujud yang tidak bergantung kepada apa pun melainkan wujudnya jua. Ia turut dikenali oleh golongan 'arifin (al-'urafā') sebagai Ke'dia'an yang Ghaib (alHuwiyyah al-Ghaybiyyah), Ghaib Mutlak (al-Ghayb alMuțlaq) dan Zat yang Esa (al-Dhāt al-Ahadiyyah). Wujud ini tidak bernama kerana Ia tidak dapat dikonsepsikan oleh akal manusia ataupun waham (deria penganggaran batin), tidak bersifat (na'at), tiada definisi (hadd) serta tidak tercapai oleh makrifat dan deria. Wujud ini ialah Ghaib Murni (al-Ghayb al-Mahd $)^{34}$, atau menurut istilah al-Attas ialah Zat Hakikat Tertinggi iaitu bersamaan dengan WujudNya atau ringkasnya Zat Allah SWT. ${ }^{35}$

Justeru, Wujud Murni iaitu Wājib al-Wujūd sama sekali tidak terdapat padanya ciri-ciri bukan wujud iaitu māhiyyah dan semua kategorinya seperti bersifat sejagat, berjuzuk, mempunyai arad, memerlukan masa dan berkehendakan ruang serta bergerak. Oleh itu, Allah SWT

32 Nasr, "Existence $($ Wujūd) and Quiddity (Māhiyyah) in Islamic Philosophy", 418.

${ }^{33}$ Christian Jambet, The Act of Being: The Philosophy of Revelation in Mullā Șadrā, terj. Jeff Fort (New York: Zone Books, 2016), 182.

${ }^{34}$ Al-Shīrāzì, al-Hikmah al-Muta 'āliyyah, II, 327.

35 Syed Muhammad Naquib al-Attas, Prolegomena to the Metaphysics of Islam: An Exposition of the Fundamental Elements of the Worldview of Islam (Kuala Lumpur: International Institute of Islamic Thought and Civilization, 1995), 268. 
sebagai Wujud Murni tidak bermāhiyyah kerana Dia tidak mempunyai sebarang batasan sebagaimana wujud mungkin yang bercampur padanya māhiyyah, sekali gus berkemungkinan wujud dan tidak wujud. ${ }^{36}$

Martabat kedua pula ialah wujud yang terhad (alwujūd al-muqayyad) iaitu wujud yang bergantung kepada wujud yang selain daripada dirinya. Ia mempunyai sifat tambahan (wașaf zà 'id) dan bersifat dengan hukum-hukum pengehadan (al-man'ūt bi ahkām maḥdüdah). Pada martabat wujud ini berdirinya segala akal dan jiwa, planetplanet, segala unsur (api, air, udara dan tanah) dan semua komposit daripada manusia, haiwan, tumbuh-tumbuhan, mineral serta maujud-maujud yang khusus. ${ }^{37}$

Seterusnya ialah martabat ketiga iaitu wujud lanjutan mutlak (al-wujūd al-munbasit al-mutlaq). Wujud ini berbeza dengan wujud martabat kedua sebelum ini kerana ia tidak dilatari oleh apa-apa sifat tertentu (wașaf khāsss) dan tidak dilingkungi oleh batasan penentuan (hadd mu'ayyun). Ia adalah hakikat lanjutan bagi semua wujud yang mungkin (hayākil al-mumkināt) dan semua māhiyyah (alwāḥ almāhiyyāt). Oleh itu, semua hakikat luaran (al-haqā'iq al$k h \bar{a} r i j i y y a h)$ terpancar daripada zat wujud ini (dhāt), modemode penentuannya (anḩ̄' ta'ayyunāt) dan pengembangannya (tatawwurāt). Justeru, wujud lanjutan mutlak ini ialah asal kepada alam, Arasy Allah SWT dan merupakan hakikat kebenaran semua ciptaan-Nya iaitu hakikat kepada semua hakikat (haqīqat al-ḥaqā'iq). ${ }^{38}$ Posisi pembahagian Șadr al-Dīn al-Shīrāzī ini membawa kepada perbincangan seterusnya mengenai pendiriannya berkenaan keasalan wujud.

\footnotetext{
${ }^{36}$ Muhammad 'Abdul-Haq, "Metaphysics of Mullā Șadrā: II”, Islamic Studies vol. 10, no. 4 (1971): 295.

${ }^{37}$ Al-Shīrāzì, al-Hikmah al-Muta 'àliyyah, II, 327.

${ }^{38}$ Ibid., 328.
} 


\section{Pendirian Șadr al-Dīn al-Shīrāzī Berkenaan Keasalan Wujud}

Secara inti patinya, sistem metafizik Șadr al-Dīn al-Shīrāzī diasaskan pada 'wujud' sebagai suatu unsur yang unik hanya kepada hakikat atau realiti. ${ }^{39}$ Wujud dalam konsepsi beliau merupakan suatu kata kerja iaitu tindakan mewujudkan atau menjadikan dan ia bukan semata-mata kata nama yang kaku. ${ }^{40}$ Bertitik tolak daripada konsepsi ini, falsafah beliau mengangkat wujud sebagai asal segala sesuatu (așālah al-wujūd). ${ }^{41}$ Dalam menetapkan pendiriannya, Șadr al-Dīn al-Shīrāzī membahaskan bahawa wujud ialah kebenaran yang diperoleh secara a priori dan swa-terbukti (self-evident) atau fitrah. Ia merupakan hakikat mutlak yang merangkumi segala sesuatu dan menenggelamkan segala sesuatu sehinggakan tidak ada perkara yang boleh berada di luar daripadanya. Sekiranya sesuatu itu dikatakan mutlak, bermakna ia tidak boleh ditakrifkan dan disifatkan lagi. ${ }^{42}$

Șadr al-Dīn al-Shīrāzī turut berpendirian bahawa wujud ialah satu hakikat objektif (wujūd 'aynī atau in concreto) yang terkandung dalamnya darjah-darjah keamatan yang membezakan antara yang mutlak dengan yang nisbi dan yang sempurna dengan yang tidak sempurna. Walau bagaimanapun, mata jasmani manusia tidak dapat melihat hakikat objektif tersebut. Hal ini sebagaimana analogi bahawa sepasang mata itu tidak tahu

\footnotetext{
${ }^{39}$ Șadr al-Dīn Muḥammad al-Shīrāzī, Risālah al-Hikmah al- 'Arshiyyah, ed. 'Abd al-Jawwād al-Husaynī (Beirut: Dār al-Ma'ārif al-Hikmiyyah, 2016), 117.

40 Ghasem Pourhassan, "Mulla Sadra and the Primacy of Existence", Wisdom and Philosophy (Hekmat va Falsafeh) vol. 6, no. 4 (2011): 30.

${ }^{41}$ Moris, Mullā Sadrā's Doctrine of the Primacy of Existence, 8-9.

42 Kamal, Mulla Sadra's Transcendent Philosophy, 3; Muhammad "Abdul-Haq, "An Aspect of the Metaphysics of Mullā Șadrā”, Islamic Studies vol. 9, no. 4 (1970): 332.
} 
dan tidak dapat melihat hakikat dirinya (mata) sendiri. ${ }^{43} \mathrm{Hal}$ ini selaras dengan firman Allah SWT yang bermaksud:

"Dia tidak dapat dilihat dan diliputi oleh penglihatan mata, sedang Dia dapat melihat (dan mengetahui hakikat) segala penglihatan (mata) dan Dia-lah yang Maha Halus, lagi Maha Mendalam pengetahuan-Nya.",44

Sungguhpun begitu, Șadr al-Dīn al-Shīrāzì tidak menyanggah analisis jasmani yang memberi capaian kepada wujud sebagai sesuatu yang dibatasi jirim (alhayūlā/hylelal-māddah/matter) dan rupa-bentuk (aș-șürah atau form). Beliau juga berpendapat bahawa analisis logik membolehkan seseorang mengetahui wujud melalui prinsip kesejagatan. Walau bagaimanapun, baginya hanya makrifat kesufian dapat menyediakan seseorang kepada penyaksian dan pengalaman secara langsung terhadap wujud secara hakiki. ${ }^{45}$

Melalui pengalamannya secara langsung terhadap hakikat wujud iaitu melalui kashf dan dhawq, Șadr al-Dīn al-Shīrāzì berhujah bahawa māhiyyah merupakan suatu abstraksi mental manusia yang bersumber daripada satu daripada mode wujud yang dikenali sebagai al-wujūd aldhihnī ${ }^{46}$ Oleh itu, wujud ialah perkara yang sebenarbenarnya mempunyai kewujudan di luar daripada hakikat mental manusia. ${ }^{47}$ Perkara ini dijelaskan oleh beliau dalam Kitāb al-Mashā 'ir ${ }^{48}$ :

"Sebelum ini, saya merupakan pembela tegar tesis keasalan māhiyyah dan abstraksi

\footnotetext{
43 ‘Abdul-Haq, "Metaphysics of Mullā Șadrā: II”, 294.

${ }^{44}$ Al-Quran 6:103, terj. Abdullah Muhammad Basmeih, Tafsir Pimpinan ar-Rahman kepada Pengertian al-Qur'an.

${ }^{45}$ Kalin, Knowledge in Later Islamic Philosophy, 224.

${ }^{46}$ Cooper, "Mulla Sadra".

47 ‘Abdul-Haq, "Metaphysics of Mullā Șadrā: II”, 295.

48 Mullā Șadrā, The Book of Metaphysical Penetrations - Kitāb alMashā 'ir: A Parallel English-Arabic Text, terj. Seyyed Hossein Nasr (Utah: Brigham Young University, 2014), 37.
} 
(i 'tibāriyyah) wujud, sehinggalah Tuhanku memberi hidayah dan saya melihat buktinya (burhāna-hu)... Maka, semua yang wujud (alwujūdāt) ialah hakikat yang asli (haqā'iq muta'așsilah), manakala māhiyyah merupakan zat-zat tetap (al-a'yān al-thābitah) yang sama sekali tidak pernah menghidu bau kewujudan yang asli... Walau bagaimanapun, bagi setiap daripadanya (wujud-wujud), terdapat ciri-ciri berzat (nu'ūtan dhātiyyah) dan makna akliah (ma'ānin 'aqliyyah) yang dipanggil dengan māhiyyah-māhiyyah."

Dalam petikan ini, Șadr al-Dīn al-Shīrāzì menjelaskan bahawa māhiyyah "tidak pernah menghidu bau kewujudan yang sebenar" kerana ia hanyalah sekadar suatu batasan kepada wujud daripada abstraksi minda manusia. ${ }^{49}$ Dengan perkataan lain, māhiyyah hanyalah suatu kemungkinan di mana dirinya sendiri bukanlah sesuatu yang wujud. Ia mengikuti wujud sebagaimana bayang-bayang yang mengikuti satu-satu individu atau objek. ${ }^{50}$ Namun, oleh sebab fungsi minda adalah untuk mempersepsikan dan menilai maujud iaitu apa jua yang tidak dapat dibezakan antara wujud dengan māhiyyah, maka mähiyyah diberi keutamaan oleh minda manusia.

Perkara ini pada hakikatnya memesongkan seseorang daripada kebenaran apabila mengatakan māhiyyah ialah asal segala sesuatu dalam hakikat objektif atau realiti luar mental. ${ }^{51}$ Șadr al-Dīn al-Shīrāzī menjelaskan implikasi kesalahan ini seperti berikut ${ }^{52}$ :

"Adapun permasalahan wujud begitu mendasarkan sebagai prinsip falsafah, asas kepada persoalan-persoalan metafizik dan

\footnotetext{
${ }^{49}$ Ibid., 38.

${ }^{50}$ Al-Shīrāzī, Risālah al-Hikmah al- 'Arshiyyah, 117.

${ }^{51}$ Rezaee \& Hashemi, "Knowledge as a Mode of Being", 22.

52 Sadrā, The Book of Metaphysical Penetrations, 3-4.
} 
berputar di sekitar ilmu tauhid ('ilm al-tawhìd), ilmu pengakhiran ('ilm al-ma'ād), kebangkitan roh dan jasad (hashr al-arwāh wa al-ajsād)... Maka, sesiapa yang jahil berkenaan makrifat wujud, kejahilannya tersebar pada ibu kepada semua subjek dan yang paling besar di antaranya, dan dengan kebingungan tentangnya, maka menjadilah dia terselindung daripada makrifat-makrifat dan ciri-cirinya, ilmu ketuhanan dan kenabian, makrifat jiwa dan pertaliannya serta pengembaliannya kepada asal segala yang berasal serta tujuannya..."

Berdasarkan petikan di atas, Șadr al-Dīn al-Shīrāzī menekankan kesalahan dalam memahami hakikat wujud memberi kesan kepada kefahaman mengenai Allah SWT dan para nabi-Nya, serta mengenai psikologi dan eskatologi manusia. Justeru, melalui sistem ontologi bahawa wujud adalah yang paling asli dan satu-satunya hakikat yang tunggal, beliau menghuraikan secara terperinci pemikiran tersebut kepada prinsip kesatuan wujud atau wahdah alwujūd dan prinsip keamatan wujud atau tashkīk al-wujūd. ${ }^{53}$

Bagi prinsip kesatuan wujud, beliau menekankan bahawa keragaman (kathrah) maujud adalah tunggal (wahdah) secara ontologinya, manakala melalui prinsip keamatan wujud, beliau menerangkan bahawa wujud menzahirkan atau memanifestasikan dirinya sesuai dengan tabiinya berdasarkan kepada kepelbagaian martabat yang tersusun. ${ }^{54}$ Apabila Șadr al-Dīn al-Shīrāzì mengatakan

\footnotetext{
${ }^{53}$ Al-Shīrāzī, Risālah al-Hikmah al- 'Arshiyyah, 44-45.

${ }^{54}$ Al-Shīrāzì, al-Hikmah al-Muta 'āliyyah, I, 35ff. Secara ringkasannya, Moris menjelaskan dalam Revelation, Intellectual Intuition and Reason in the Philosophy of Mulla Sadra, 190-191: "On the basis of the metaphysical principle of the sole reality of Being, Mulla Sadra expounds his doctrines of the transcendent unity of Being which asserts that the multiplicity of existents are metaphysically one and the analogical gradation of Being which states that Being manifests
} 
keragaman itu tunggal secara ontologi, hal ini tidak bermakna beliau mengatakan bahawa wujud makhluk itu sama dengan wujud Khāliq (panteisme) atau yang wujud hanyalah semata Tuhan (monisme) ${ }^{55}$ Hal ini kerana, beliau ada menjelaskan pendiriannya ${ }^{56}$ :

"... yang paling sempurna (akmal) dan paling kuat keamatannya (ashad) dalam kalangan wujud-wujud (al-wujūdāt) ialah Wujud Allah yang Maha Benar (al-Wujūd al-Haqq) yang Dia itu Wujud Hakiki Murni (Maḥ̣ al-Haqiqah alWujūd), Dia tidak serupa dengan apa-apa pun melainkan Wujud dan Dia paling terzahir (azhar) dan paling bersinar (awdah) dalam kalangan wujud-wujud yang nisbah kepada Diri-Nya."

Oleh sebab kelimpahan penzahiran Diri-Nya, manusia terhalang (muhtajibān) daripada memahami-Nya dengan akal (al-'uqūl) dan melihat-Nya dengan penglihatan mata (al-abșār). ${ }^{57}$ Walau bagaimanapun, jiwa-jiwa yang sentiasa disucikan sahaja dapat memahami-Nya. Hal ini membawa kepada prinsip seterusnya iaitu gerakan jauhar atau alharakat al-jawhariyyah. Prinsip ini merupakan antara penyingkapan terkhusus yang diperoleh oleh Sadr al-Dīn al-Shīrāzì melalui intuisi dalam menuruti jejak langkah sistem ontologi Ibn 'Arabī. ${ }^{58}$

Itself in accordance with Its nature with various degrees and grades of intensity."

55 Açıkgenç, Being and Existence in Șadrā and Heidegger, 134.

${ }^{56}$ Al-Shīrāzī, Risālah al-Hikmah al- 'Arshiyyah, 45-46.

${ }^{57}$ Ibid., 46.

${ }^{58}$ Christian Jambet, The Act of Being: The Philosophy of Revelation in Mullā Șadrā, 185. 


\section{Huraian Keasalan Wujud Șadr al-Dīn al-Shīrāzī dalam Konteks Jiwa Manusia}

Secara umumnya, maujud-maujud yang beragam sentiasa dalam proses menjadi (in a process of becoming) dan perkara ini mewajibkan berlakunya perubahan. ${ }^{59}$ Secara kebiasaannya, dalam falsafah, perubahan atau pergerakan arad adalah sesuatu yang lazimnya difahami seperti perubahan kualiti (al-kayfiyyah, misalnya warna) dan kuantiti (al-kammiyyah, misalnya ketinggian).

Namun, Șadr al-Dīn al-Shīrāzī dengan penyabitan prinsip-prinsip yang disebutkan sebelum ini, memperkenalkan pula prinsip yang menggerakkan tenaga dari satu alam ke alam yang lain. ${ }^{60}$ Hal ini kerana, setiap maujud secara tekal bergerak dalam jauharnya, atau dalam konteks manusia iaitulah jiwanya. Perkara ini dijelaskannya seperti berikut ${ }^{61}$ :

"Sesungguhnya wujud individu (al-wujūd alshakhși) boleh bergerak berdasarkan keamatan dan kekuatan. Sesungguhnya, ke'dia'an jauhar (al-huwiyyah al-jawhariyyah) sentiasa meningkat keamatan (yushtad) dan bergerak dalam jauharnya (yutaharik fi jawhariyyah) melalui gerakan berterusan ke atas ciri kesatuan yang berhubungan (na 'at al-wahdah alittișāliyyah), yang bersatu dengan penghubung juga bersatu dengan wujud dan pengindividuan."

Menurut Șadr al-Dīn al-Shīrāzī, oleh sebab perhubungan itu adalah satu pada wujudnya yang satu, maka māhiyyahnya juga ialah satu. Apabila mencapai suatu had yang tertentu (hudūd mafrụ̈̂h), māhiyyah yang mengikuti wujud akan menentukan (muta'ayyin) rupa-

\footnotetext{
${ }^{59}$ Ibid., 191.

${ }^{60}$ Ibid., 185-186.

${ }^{61}$ Al-Shīrāzī, Risālah al-Hikmah al- 'Arshiyyah, 115-116.
} 
bentuk wujud tersebut. Justeru, secara 'hipotesisnya', semakin meningkat keamatan dan kekuatan wujud, semakin tersempurnalah zatnya, semakin utuh makna dan māhiyyahnya, semakin bertambah kesan dan perbuatannya. ${ }^{62}$ Dalam hal ini, beliau memberi satu refleksi berkenaan rantaian 'hipotesis' tersebut ${ }^{63}$ :

"Tidakkah diperhatikan bahawa oleh sebab jiwa haiwan (nafs al-hayawān) lebih kuat daripada jiwa-jiwa lain seperti jiwa tumbuhan (nafs annabātiyyah) dan rupa-bentuk-rupa-bentuk unsur, ia mampu melakukan perbuatanperbuatan tumbuhan, mineral (al-jamād) dan unsur-unsur (al- 'anāșir), malah perbuatan yang melebihi mereka semua? Begitu juga jiwa manusia yang melakukan perbuatan semua jiwa tersebut, malah berkeupayaan berkata-kata dan diberi akal melakukan apa jua dengan kehendak (al-inshā')."

Berdasarkan petikan di atas, dapat diperhatikan bahawa jiwa manusia pada hierarki atau hadnya merangkumi kesemua jiwa yang berada di bawahnya iaitu yang berada di alam unsur (api, angin, tanah dan air), alam mineral (misalnya ferum atau besi, kalsium, natrium), alam tumbuh-tumbuhan dan alam haiwan. Pergerakan pada setiap peringkat jiwa dalam ranah jasmani yang dipanggil cairan wujud atau sayāl al-wujūd ini melibatkan perubahan segala sesuatu yang terdiri daripada jirim dan rupa-bentuk. Ia melibatkan dua keadaan iaitu sama ada secara perbakatan (bi al-quwwah) atau secara perbuatan (bi al-fi $l){ }^{64}$

Dalam menghuraikan idea Șadr al-Dīn al-Shīrāzī ini, Moris menjelaskan bahawa, semasa manusia merupakan wujud benih (sperma dan ovum) pada awalnya, ia wujud sebagai jirim mineral secara perbuatan dan rupa-bentuk

\footnotetext{
62 Ibid., 117.

${ }^{63} \mathrm{Ibid}$.

${ }^{64}$ Ibid., 70.
} 
tumbuhan secara perbakatan. Apabila ia disenyawakan dan berkembang sebagai wujud zigot, blastosista, embrio dan fetus, ia berada sebagai jirim tumbuhan secara perbuatan dan rupa-bentuk haiwan secara perbakatan. Seterusnya, apabila dilahirkan sebagai wujud bayi sehingga mencapai usia kanak-kanak, ia wujud sebagai jirim haiwan secara perbuatan dan rupa-bentuk manusia yang berfikir secara perbakatan. Akhir sekali, apabila mencapai umur kematangannya, wujud kanak-kanak tadi menjadi manusia yang berfikir secara perbuatan. ${ }^{65}$

Walau bagaimanapun, wujud manusia tidak berhenti pada had ini jika hal ini dirujuk dari perspektif al-Qur'an dan hadis. Menyedari akan hal ini, prinsip al-harakat aljawhariyyah Șadr al-Dīn al-Shīrāzī ini merangkumi pergerakan jauhar selepas kematian dari alam dunia. Sungguhpun begitu, kemungkinan yang ada pada seseorang manusia apabila berada di alam dunia ini adalah sama ada dia akan menjadi serupa dengan jiwa malaikat, syaitan, haiwan belaan atau haiwan pemangsa. Sekiranya ilmu dan takwa mendominasi wujud seseorang manusia, dia berbakat mengambil rupa-bentuk malaikat. Sebaliknya, sekiranya kelicikan, tipu-daya dan kejahilan yang dirinya tidak menyedari akan kejahilannya itu atau dipanggil aljahl al-murakkab menyelubungi wujud seseorang manusia, dia berbakat mengambil rupa-bentuk syaitan. ${ }^{66}$

Selain itu, sekiranya wujud seseorang manusia hanya semata-mata hidup untuk memuaskan jiwa syahwatnya

\footnotetext{
${ }^{65}$ Moris, Revelation, Intellectual Intuition and Reason in the Philosophy of Mulla Sadra, 105. Peringkat-peringkat manusia yang diperincikan dari sperma hingga fetus diperoleh daripada Susan Tucker Blackburn, Maternal, Fetal, and Neonatal Physiology: A Clinical Perspective, 4th ed. (Missouri: Saunders Elsevier, 2007), 77ff. Untuk perbincangan mengenai teori evolusi jiwa menurut Șadr al-Dīn al-Shīrāzī, rujuk Ali Arshad Riahi, Mohammad Nassrifahani \& Mehdi Jafarzadeh, "Mulla Sadra and Evolution Theory", International Journal of Islamic Thought 8, (December 2015): 4-8.

${ }^{66}$ Al-Shīrāzī, Risālah al-Hikmah al- 'Arshiyyah, 101.
} 
(an-nafs ash-shahwiyyah) atau jiwa bengisnya (an-nafs alghadabiyyah), maka dia akan mengambil rupa-bentuk haiwan belaan seperti baghal, keldai, anjing dan babi atau rupa-bentuk haiwan pemangsa seperti singa, serigala dan burung helang. Maka, yang diambil ialah rupa-bentuk haiwan-haiwan tersebut, bukanlah bersama-sama dengan jirimnya yang terkhusus ( $m \bar{a} d d a h$ al-makhșūṣah). ${ }^{67}$

Oleh itu, berasaskan kemungkinan-kemungkinan yang mendominasi jiwa manusia yang memberi kesan kepada akhlaknya, Șadr al-Dīn al-Shīrāzī menjelaskan bahawa:

“... seseorang (manusia) akan dibangkitkan pada Hari Kiamat dengan rupa-bentuk yang munasabah untuknya, maka manusia akan terbahagi kepada spesies yang pelbagai (anwā kathīrah) sebagaimana yang diperkatakan mengenainya dalam Kitab Ilahi... (Ja'fār) aṣȘādiq berkata, 'manusia akan dibangkitkan mengikut rupa-bentuk amalan mereka (șwar a'mālahum)',"68

Oleh yang demikian, jiwa pada hakikatnya menjadi titik pertemuan antara alam dunia atau ranah jasmani dengan alam akhirat atau ranah rohani. Ketika di alam dunia, jiwa menjadi rupa-bentuk kepada setiap bakat atau potensi yang disebutkan sebelum ini, namun apabila di alam akhirat kelak, jiwa menjadi 'jirim' kepada setiap rupabentuk yang diaktualisasikan. ${ }^{69}$ Justeru, tidak ada isu transmigrasi jiwa atau al-tanāsukh dalam pemikiran Șadr al-Dīn al-Shīrāzī kerana beliau sememangnya menyatakan kemustahilannya. Pergerakan jiwa kepada akal secara perbakatan kepada akal secara perbuatan pula adalah sangat nadir berlaku sama ada semasa di alam dunia mahupun alam akhirat. Hal ini antaranya berlaku kepada nabi-nabi

\footnotetext{
${ }^{67}$ Ibid., 101-102.

${ }^{68}$ Ibid., 102.

${ }^{69}$ Ibid., 104-105.
} 
dan para rasul. ${ }^{70}$ Beliau memetik ayat berikut untuk membuktikan perkara ini, mafhumnya ${ }^{71}$ :

"Katakanlah (wahai Muhammad), sesungguhnya aku hanyalah seorang manusia serupa dengan kalian (basharun mithlukum), diwahyukan kepadaku bahawa Tuhan kalian hanyalah Tuhan yang Satu..."

Menurut Șadr al-Dīn al-Shīrāzī, keserupaan (mithl) Nabi Muhammad SAW dengan jiwa manusia yang lain (bashar) adalah sebelum baginda SAW menerima wahyu. Namun, selepas penurunan wahyu, jiwa baginda SAW bergerak daripada akal secara perbakatan kepada akal secara perbuatan yang lebih tinggi daripada setiap nabi dan malaikat lainnya, menjadikan baginda SAW paling hampir (aqrab) dengan Allah SWT. ${ }^{72}$ Selain daripada jiwa para nabi dan rasul yang sememangnya sudah tersempurna, kebanyakan jiwa manusia tidak bergerak kepada akal secara perbuatan di alam akhirat kerana ketidaksempurnaan jiwa mereka (al-nufūs al-nāqișah).

Oleh yang demikian, Șadr al-Dīn al-Shīrāzī menegaskan pendiriannya yang berbeza dengan pendirian ahli-ahli falsafah sebelumnya iaitu bahawa kebangkitan jiwa manusia adalah mengikut aktualisasi rupa-bentuk yang akan menjadi landasan ( $m a b d a$ ') kepada pembeza akhirnya (fașl al-akhīr atau differentia). ${ }^{73}$ Justeru, akhlak manusia semasa hidup dalam ranah jasmani yang menyelubungi jiwanya yang akan menentukan rupa-bentuknya secara perbuatan dalam ranah rohani. Daripada perbincangan ini juga, jelaslah bahawa hakikat asas yang menjadi kerangka kepada pemikiran Șadr al-Dīn al-Shīrāzī iaitu wujud merupakan dasar untuk beliau menjelaskan keindividualan

\footnotetext{
${ }^{70}$ Ibid., 105-106.

71 Al-Quran 18:110, terj. Abdullah Muhammad Basmeih, Tafsir Pimpinan ar-Rahman kepada Pengertian al-Qur'an.

72 Al-Shīrāzī, Risālah al-Hikmah al- 'Arshiyyah, 105-106.

${ }^{73}$ Ibid., 114.
} 
dan pergerakan jauhar dalam mengaktualisasikan bakat yang terkandung pada jiwa manusia. ${ }^{74}$

Beliau juga berupaya menghuraikan secara rasional perubahan hakikat manusia dari satu ranah ke ranah yang lain melalui pemikirannya tentang wujud. Perkara ini adalah berpandukan cahaya al-Qur'an, sebagaimana ayat yang pernah dipetik dalam Risālah al-Hikmah al'Arshiyyah'

"Maka adakah patut kalian menyangka bahawa Kami menciptakan kalian tanpa sebarang hikmah pada penciptaan itu dan bahawasanya kamu tidak akan dikembalikan kepada Kami?"

\section{Lakaran Konsep Idea Wujud Menurut Șadr al-Dīn al- Shīrāzì}

Bagi meringkaskan idea kompleks Șadr al-Dīn al-Shīrāzī mengenai pertalian antara wujud dengan jiwa manusia secara khusus, makalah ini melakarkan satu rajah konseptual sebagaimana yang dipaparkan pada Rajah 1 . Rajah 2 pula memperincikan kemungkinan-kemungkinan bakat atau potensi yang disebutkan oleh beliau yang berlaku kepada rupa-bentuk jiwa manusia semasa di alam dunia dan selepas kematian.

${ }^{74}$ Eiyad S. al-Kutubi, Mullā Sadrā and Eschatology: Evolution of Being (New York: Routledge, 2015), 35.

75 Al-Quran 23:115, terj. Abdullah Muhammad Basmeih, Tafsir Pimpinan ar-Rahman kepada Pengertian al-Qur'an. 
Mohd Syahmir, "Pemikiran Sadr al-Din al-Shirazi tentang Wujud," Afkār Vol.

21 Issue 2 (2019): 1-32

Rajah 1. Pertalian antara Wujud dengan Jiwa Manusia menurut Pemikiran Șadr al-Dīn al-Shīrāzī

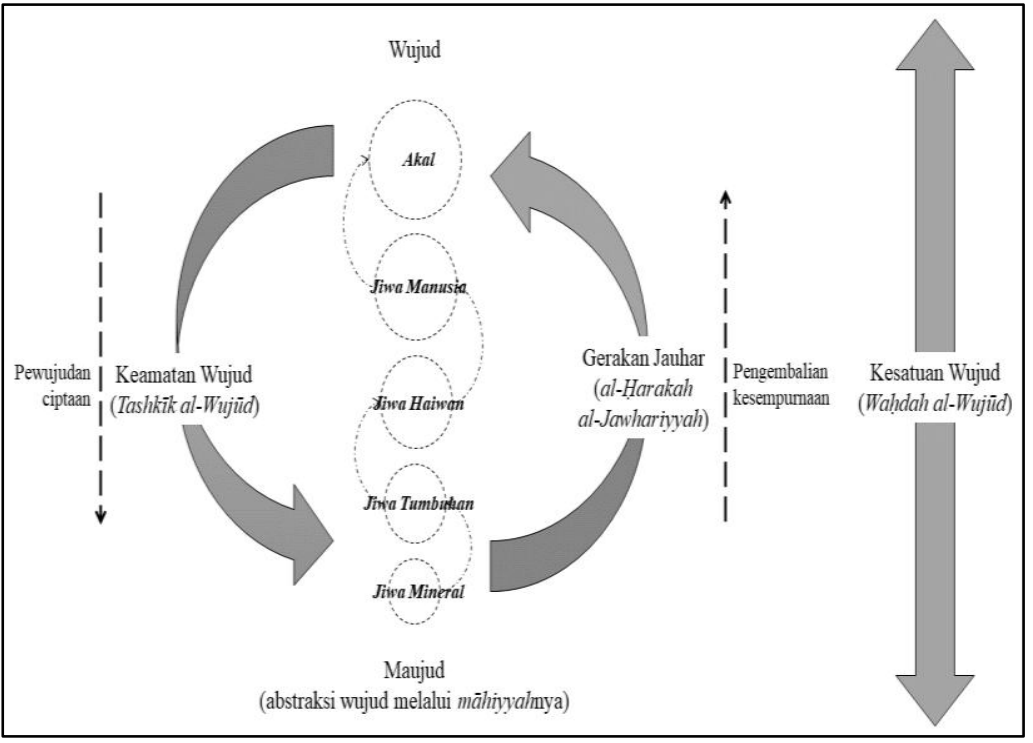

Berdasarkan Rajah 1, keseluruhan hakikat yang asli menurut Șadr al-Dīn al-Shīrāzī ialah wujud dan hal ini menunjukkan adanya kesatuan wujud dalam konteks jiwa manusia. Peringkat-peringkat penciptaan berlaku apabila wujud manusia memanifestasi dirinya kepada mode-mode wujud (jiwa-jiwa tertentu), maka mode-mode wujud tersebut melalui proses pewujudan yang digredkan mengikut darjah-darjah keamatan wujudnya. Sebaliknya, maujud manusia dengan ketidaksempurnaannya sentiasa bergerak ke arah kesempurnaan wujud secara dinamik melalui prinsip gerakan jauhar. Pada umumnya, lakaran Rajah 1 ini juga boleh diabstraksikan dalam konteks perbincangan hubungan tiga martabat wujud yang dibincangkan dalam bahagian kedua perbincangan makalah ini (al-Wujūd aș-Șarf, al-wujūd al-munbasiṭ al-muțlaq dan al-wujūd al-muqayyad).

Berikutnya, dalam Rajah 2, dilakarkan pula pemikiran Șadr al-Dīn al-Shīrāzī mengenai rupa-bentuk yang 
Mohd Syahmir, "Pemikiran Sadr al-Din al-Shirazi tentang Wujud," Afkār Vol.

21 Issue 2 (2019): 1-32

mungkin untuk diambil rupa-bentuknya oleh jiwa manusia. Jiwa manusia dalam ranah jasmani diaktualisasikan oleh komposit (murakkab) antara jirim dengan rupa-bentuk. ${ }^{76}$ Walau bagaimanapun, terdapat empat kemungkinan rupabentuk secara perbakatan yang boleh diambil oleh jiwa manusia iaitu malaikat, haiwan belaan, haiwan pemangsa dan syaitan. Namun, kesemua rupa-bentuk berbakat ini diaktualisasikan sebagai 'jirim' jiwanya apabila dibangkitkan di alam akhirat kelak. Pembalasan terhadap jiwa manusia juga adalah berpandukan rupa-bentuk berbakat yang diaktualisasikan oleh jiwa iaitu sama ada di syurga atau di neraka.

Rajah 2. Kemungkinan Rupa-Bentuk yang Diaktualisasikan oleh Jiwa Manusia menurut Pemikiran Șadr ad-Dīn ash-Shīrāzī

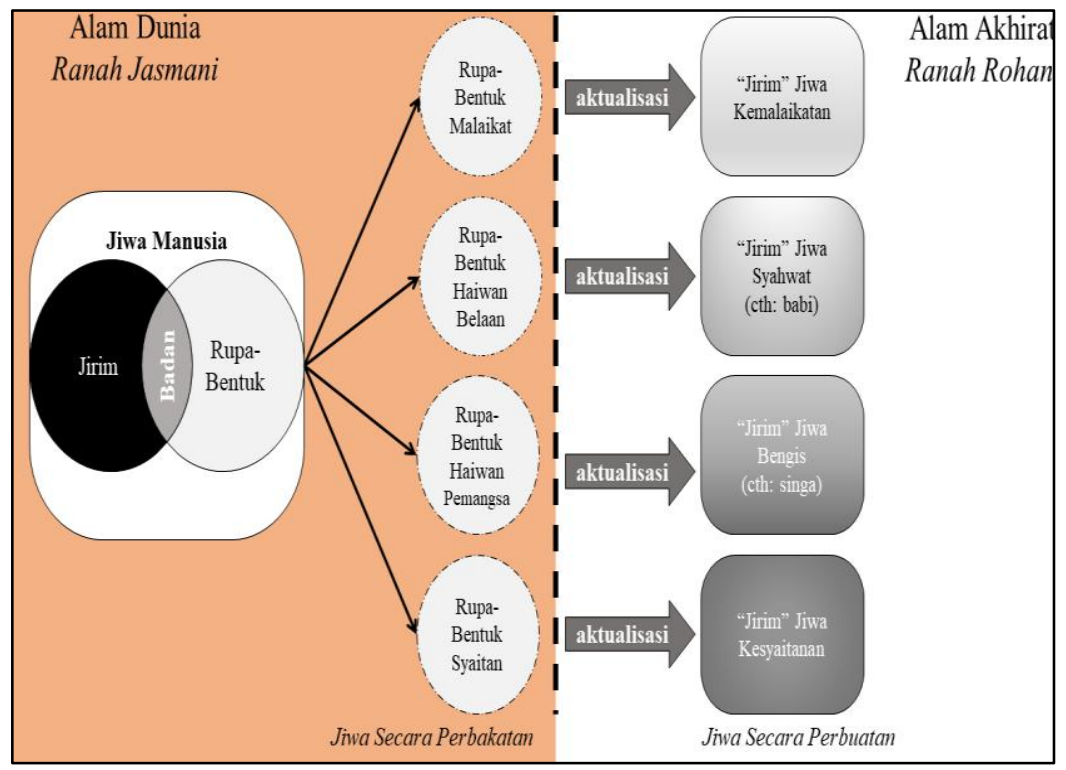

${ }^{76}$ Al-Attas, Prolegomena to the Metaphysics of Islam, 227-228. 


\section{Kesimpulan}

Secara umumnya, Șadr al-Dīn al-Shīrāzī melahirkan empat prinsip penting dalam sistem falsafahnya atau secara lebih khusus dalam sistem metafiziknya. Pertama, prinsip keasalan wujud (așālah al-wujūd); kedua, prinsip kesatuan wujud (wahdah al-wujūd); ketiga, prinsip keamatan wujud (tashkīk al-wujūd); dan keempat, prinsip gerakan jauhar (al-harakat al-jawhariyyah). Keempat-empat prinsip ini merupakan pemikiran beliau yang asli atas dasar falsafah yang terabsahkan. Terabsahkan, dalam konteks ini, dapat diperhatikan daripada keseluruhan perbincangan dalam makalah ini.

Șadr al-Dīn al-Shīrāzī tidak hanya berasaskan kepada hujah-hujah kewacanaan yang logik, malah, beliau juga berasaskan kepada pengalaman kerohaniannya seperti kashf dan dhawq serta disahkan berdasarkan kefahamannya terhadap al-Qur'an dan hadis. Perkara inilah yang menjadikan pemikirannya mampu membawa dimensi baharu dalam falsafah Islam. Malah, untuk memperkukuhkan keimanannya kepada asal segala sesuatu daripada Allah SWT, Wujud Murni yang Wajib WujudNya dan adanya pengembalian jiwa ke alam yang baqa yang secara jelas bertunjangkan wahyu, Șadr al-Dīn alShīrāzì mewacanakan secara falsafah berkenaan perkembangan dan kebangkitan jiwa manusia selepas kematian.

\section{Penghargaan}

Penghargaan khas ditujukan kepada pihak Universiti Sains Malaysia yang telah membiayai kajian ini melalui Geran Penyelidikan Jangka Pendek, Universiti Sains Malaysia (2018-2020) [304/PHUMANIT1/6315177] dalam penyelidikan yang bertajuk Konsep Objektiviti dalam Falsafah Penyelidikan Islam: Kajian Pemikiran Al-Biruni dan Sadr Ad-Din Shirazi. 
Mohd Syahmir, "Pemikiran Sadr al-Din al-Shirazi tentang Wujud," Afkār Vol.

21 Issue 2 (2019): 1-32

\section{Rujukan}

'Abdul-Haq, Muhammad, "An Aspect of the Metaphysics of Mullā Șadrā”, Islamic Studies vol. 9, no. 4 (1970): 331-353.

'Abdul-Haq, Muhammad, "Metaphysics of Mullā Șadrā: II”, Islamic Studies vol. 10, no, 4 (1971): 291-317.

Açıkgenç, Alparslan. Being and Existence in Șadrā and Heidegger: A Comparative Ontology. Kuala Lumpur: International Institute of Islamic Thought and Civilization, International Islamic University Malaysia, 1993.

Aini, Zulkefli, Saari, Che Zarrina \& Abdul Ghani, Mohamad Zulkifli, "Pendekatan Dakwah al-Wasațiyyah Syeikh Abdul Rauf Ali al-Fansuri”, Jurnal Akidah \& Pemikiran Islam (Afkar) vol. 20, issue 1 (2018): 179-212. Al-Allaf, Mashhad. The Essential Ideas of Islamic Philosophy: A Brief Survey. New York: The Edwin Mellen Press, 2006.

Al-Attas, Syed Muhammad Naquib. Prolegomena to the Metaphysics of Islam: An Exposition of the Fundamental Elements of the Worldview of Islam. Kuala Lumpur: International Institute of Islamic Thought and Civilization, 1995.

Basmeih, Abdullah Muhammad. Tafsir Pimpinan arRahman kepada Pengertian al-Qur'an, ed. Muhammad Noor Ibrahim. Kuala Lumpur: Darul Fikir, 2001.

Blackburn, Susan Tucker. Maternal, Fetal, and Neonatal Physiology: A Clinical Perspective, 4th ed. Missouri: Saunders Elsevier, 2007.

Cooper, John. "Mulla Sadra (Sadr al-Din Muhammad alShirazi) (1571-1640)". Dicapai pada 19 Januari 2017. http://www.muslimphilosophy.com/ip/rep/H027.htm.

Drajat, Amroeni. Suhrawardi: Kritik Falsafah Peripatetik. Yogyakarta: LKiS, 2005. 
Ernst, Carl W. "Sufism and Philosophy in Mulla Sadra". World Congress on Philosophy of Mulla Sadra, Tehran, Mei 1999.

Izutsu, Toshihiko. The Concept and Reality of Existence. Kuala Lumpur: Islamic Book Trust, 2007.

Jambet, Christian. The Act of Being: The Philosophy of Revelation in Mullā Sadrā, terj. Jeff Fort. New York: Zone Books, 2016.

Kalin, Ibrahim. Knowledge in Later Islamic Philosophy: Mullā Șadrā on Existence, Intellect and Intuition. Oxford: Oxford University Press, 2010.

Kamal, Muhammad. Mulla Sadra's Transcendent Philosophy. Aldershot: Ashgate, 2006.

Al-Kutubi, Eiyad S. Mullā Sadrā and Eschatology: Evolution of Being. New York: Routledge, 2015.

Munsoor, Mohamed Safiullah \& Saari, Che Zarrina, "Knowledge and Islam on the Non-Rational and Rational-Heart-Brain Inter-Connection: A Classical Islamic Scholarly Perspective", Jurnal Akidah \& Pemikiran Islam (Afkar) vol. 19, issue 1 (2017): 129-162.

Moris, Megawati. Mullā Sadrā's Doctrine of the Primacy of Existence (Așālat al-Wujūd). Kuala Lumpur: International Institute of Islamic Thought and Civilization, International Islamic University Malaysia, 2003.

Moris, Zailan. Revelation, Intellectual Intuition and Reason in the Philosophy of Mulla Sadra: An Analysis of the alHikmah al-'Arshiyyah. New York: RoutledgeCurzon, 2003.

Nasr, Seyyed Hossein. Sadr ad-Dīn Shīrāzì and His Transcendent Theosophy: Background, Life and Works. Tehran: Imperial Iranian Academy of Philosophy, 1978. Nasr, Seyyed Hossein, "Existence (Wujūd) and Quiddity (Māhiyyah) in Islamic Philosophy", International Philosophical Quarterly vol. 24, no. 4, issue 116 (December 1989): 409-428. 
Nur, Muhammad. Wahdah al-Wujud Ibn 'Arabi dan Filsafat Wujud Mulla Shadra. Makassar: Chamran Press, 2012.

Pourhassan, Ghasem, "Mulla Sadra and the Primacy of Existence", Wisdom and Philosophy (Hekmat va Falsafeh) vol. 6, no. 4 (2011): 29-38.

Rahman, Fazlur. The Philosophy of Mullā Șadrā (Sadr adDìn Muhammad Shīrāzī). Lahore: Suhail Academy, 2005.

Rezaee, Hossein Sheykh, dan Hashemi, Mohammad Mansur. "Knowledge as a Mode of Being: Mulla Sadra's Theory of Knowledge", Sophia Perennis vol. 4 (Autumn 2009): 19-44.

Riahi, Ali Arshad, Nassrifahani, Mohammad, dan Mehdi Jafarzadeh. "Mulla Sadra and Evolution Theory", International Journal of Islamic Thought vol. 8 (December 2015): 1-12.

Rizvi, Sajjad H. Mulla Sadra Shirazi: His Life and Works and the Sources for Safavid Philosophy. New York: Oxford University Press, 2007.

Rizvi, Sajjad. "Mulla Sadra". The Stanford Encyclopedia of Philosophy, dicapai 6 Ogos 2017, http://plato.stanford.edu/entries/ mulla-sadra/.

Saari, Che Zarrina \& Mohd Akib, Mohd Manawi, "Beberapa Persoalan Berkaitan Konsep Insan Menurut Fakhr al-Dīn al-Rāzì," Jurnal Akidah \& Pemikiran Islam (Afkar) vol. 19, Special Issue (2017): 87-114.

Șadrā, Mullā. The Book of Metaphysical Penetrations Kitāb al-Mashā ir: A Parallel English-Arabic Text, terj. Seyyed Hossein Nasr. Utah: Brigham Young University, 2014.

Safavi, Seyed G., "Mulla Sadra's Life and Philosophy", Trancendent Philosophy vol. 13 (Disember 2012): 2196. 
Al-Shīrāzī, Șadr al-Dīn Muḥammad. Al-Hikmah alMuta 'āliyyah fì al-Asfār al- 'Aqliyyah al-Arba 'ah al-Juz' al-Awwal. Beirut: Dār Ihȳā' at-Turāth al-'Arabī, 1990.

Al-Shīrāzī, Șadr al-Dīn Muḥammad. Al-Maz̄āhir alIlāhiyyah fì Asrār al-'Ulūm al-Kamāliyyah, ed. alSayyid Jalāl al-Dīn al-Āshtiyānī. Iran: Mu'assasah Būstān Kitāb, 2008.

Al-Shīrāzī, Șadr al-Dīn Muhammad. Risālah al-Hikmah al'Arshiyyah, ed. 'Abd al-Jawwād al-Ḥusaynī. Beirut: Dār al-Ma'ārif al-Hikmiyyah, 2016.

Zarkasyi, Hamid Fahmy, "The Philosophy of Mulla Sadra: Being a Summary of His Book al-Hikmah alMuta'äliyah fi al-Asfār al-'Aqliyyah al-Arba 'ah", TSAQAFAH vol. 5, no. 2 (2009): 325-351. 
Mohd Syahmir, "Pemikiran Sadr al-Din al-Shirazi tentang Wujud," Afkār Vol.

21 Issue 2 (2019): 1-32 